\title{
Studying Restoration Painting
}

\section{A Case Study of a Modification ${ }^{1}$}

\author{
Emilia Laaksovirta
}

doi.org/10.23995/tht.112171

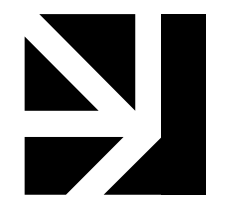

In this article I discuss the history of restoration painting through art history and art conservation with the help of a case study. Restoration painting has a long history as a part of art conservation. The methods and theories of restoration painting have evolved along with the process of art conservation into a discipline of academic study. I discuss an old method of restoration painting called overpainting by means of a case study. Overpainting was quite a common practice, until it became viewed as unethical and unprofessional. The case study is a painting that was modified by overpainting. The modifications were done most likely at the same time as damages to the canvas were repaired, possibly sometime before the middle of the $20^{\text {th }}$ century. The old overpaintings were removed during a complete restoration of the painting in 2018-2019. The removal of the overpaintings uncovered new possibilities for the interpretation of the motif of the painting. I briefly discuss the idea of the Italian tratteggio method of restoration painting, which in my view demonstrates a scientific turn in conservation. I also discuss new ways of using scientific methods of collecting data for decision making in restoration.

Keywords: artconservation, art history, overpainting, restoration painting, science in conservation

1 I would like to thank all those who have provided feedback, comments, and assistance during various parts of writing this article: my supervisors Tutta Palin and Riikka Stewen, TAHITI editors and referees, art history seminar group, conservator colleagues, The Kunsthistorisches Museum in Vienna, Annika Niemelä, Sarah Maisey, Elizabeth Nyman and Jonne Lehtimäki. All the shortcomings of the text are my own. 
Restoration painting is a common conservation practice. The development of conservation and restoration as an academic discipline has been established through adapting the research methods of the natural sciences for material investigations and working practices. In this article, the history of restoration painting is approached by means of a case study of a painting depicting a female figure holding grapes and wearing a vine leaf garland. The painting had large areas of overpainting and modifications that were done as part of an earlier conservation and restoration intervention. With the removal of the overpainting as part of the conservation, the painting's motif was opened up from a simple portrait of a woman into an androgynous Bacchic or bacchante one.

Methodology and attitudes adopted from natural sciences have acted as a way of controlling conservation and restoration practices and have led to the development of a specific scientific method of restoration painting, called tratteggio. Tratteggio was developed in the 1930s in Italy by Cesare Brandi as a solution to combat unethical and lavish restoration painting. The tratteggio restoration is clearly discernible from the original painting and restricted to the area of loss, unlike previous overpainting modifications. The quest for objectivity and truth characteristic of natural science when used as a method in conservation has been questioned within the field, while, in contrast, new and innovative ways of using scientifically acquired data have been applied in contemporary conservation and restoration. The act of restoration painting calls for knowledge of materials, the ethics of conservation, and creativity and skill in painting. A conservator-restorer must balance their actions between science and creativity. The act of restoration painting requires creativity and skilful craftmanship, both of which may be elusive to the so called hard sciences.

\section{Restoration painting as a phenomenon}

The appearance of a work of art changes over time and also through different conservation and restoration treatments carried out on it. The general public is mostly unaware of these treatments and changes, although museums around the world are increasingly sharing snippets of information about their conservation work through social media and in their exhibition spaces and publications. ${ }^{2}$ The treatment history of a painting can both conceal and allow the ways an artwork can be seen at a given time. The material existence of a painting is inextricably linked to how its subject matter is seen and interpreted, and often subsequent restorations may have altered the appearance of a painting so extensively that even its subject is no longer legible, or it has been totally obscured.

In this article, I will present a brief overview of the history of restoration painting as part of art conservation as opposed to the old practice of overpainting by discussing the case study of a painting that has undergone restoration; the painting depicts a womanly figure dressed in what seemed to be some sort of pleated garment with vine leaves and grapes. Removing the old restorations and overpainting revealed a significant modification of the painting's character. I will also discuss some of the terminology and attitudes associated with restoration painting in art conservation. Restoration painting as part of contemporary art conservation practice has evolved from a craft and artisanal activity to an often critically discussed and sometimes scien-

A recent publicly shared project is the material investigation and restoration of The Night Watch (1642) by Rembrandt van Rijn in the Rijksmuseum in the Netherlands. The Rijksmuseum decided to build a glass case surrounding the enormous painting, so that it could be on display through the process. "Operation Night Watch", accessed 17.12.2020, https://www.rijksmuseum.nl/en/nightwatch. 
tifically reasoned method of the pictorial reintegration of damaged areas or losses in paintings. ${ }^{3}$

An old practice of overpainting can be understood as the modification of artworks by painting over the original surface by someone other than the artist themselves. This is a practice commonly seen in paintings that have undergone conservation and been restored before the ideas of modern conservation became widespread. It demonstrates the transformation of restoration painting from an uncontrolled, and from a contemporary perspective, an ethically uninformed activity to a professional restoration method. It has to be noted here, that not all older restorations were done "badly" or with the intention to modify or alter the paintings. However, the ethics of restoration were largely non-existent before the $19^{\text {th }}$ century. Restoration painting as a part of contemporary art conservation follows the ethical guidelines of conservation that condemn the use of unsuitable materials (i.e., paints and other material that are difficult to remove or that would cause damage to the original surface) and the speculative filling in of an area of loss. ${ }^{4}$ This is a problem in paintings that have large areas of damage or loss that cannot be traced to a reliable source such as photographs, lithographs, replicas or remakes, to guide the restoration process. An interesting example of this kind of large area of loss is provided by a painting restored at the Tate Britain, the Destruction of Pompeii and

3 Salvador Muñoz Viñas, Contemporary Theory of Conservation (Oxford: Routledge, 2005), xi-xii. Muñoz Viñas claims that contemporary theory of conservation started to develop in the 1980s, since the Burra Charter was published by Australia ICOMOS. The Burra Charter is an adaptation of the Venice Charter for the Conservation and Restoration of Monuments and Sites. "Burra Charter \& Practice Notes", accessed 17.12.2020, https://australia.icomos.org/publications/burra-charter-practice-notes/.

4 Magdalena Grenda, "Tratteggio retouch and its derivatives as an image reintegration solution in the process of restoration. Case study: restoration of a 20th century lithograph film poster by Stefan Norblin," CeROArt. Conservation, exposition, Restauration d'Objets d'Art, no. 1 (15 November 2010), paragraph 11.
Herculaneum (1821) by John Martin, where the conservator Sarah Maisey had recourse to sound archival sources for the extensive restoration. ${ }^{5}$ Maisey used recent scientific methods to help the decision making, such as eye movement tracking and digital restoration models. This case seems to follow the continuum of science being used as best practice in conservation and restoration, both in research and decision making.

Without the archival sources available in the case of the Tate Britain painting, a restoration as extensive as that would not have been possible or ethical considering contemporary conservation ethics. ICOM-CC (International Council of Museums, Committee for Conservation) states that "Restoration is action taken to make a deteriorated or damaged artefact understandable, with minimal sacrifice of aesthetic and historic integrity." As regards the co-operation of a conservator-restorer and curator the ICOM-CC also state that: "Together they must distinguish between the necessary and the superfluous, the possible and the impossible, the intervention that enhances the qualities of the object and that which is detrimental to its integrity." ${ }^{\prime}$ These statements underline that all conservation and restoration activity should strive to maintain the integrity of an object and refrain from unnecessary interventions. Integrity of the object and the level of necessity of the conservation treatments and interventions are concepts that are under continuous discussion and have undergone significant changes in the past decades. Conservator David Bomford discusses in an article the change in attitudes towards a formerly common procedure of wax-lining that was critically re-evaluated in a

5 Sarah Maisey, Patricia Smithen, A. Soler \& Tim Smith,"Recovering from destruction: the conservation, reintegration and perceptual analysis of a flood-damaged painting by John Martin," ICOM-CC: 16th triennial conference, Lisbon, 19-23 September 2011, Paris: ICOM Committee for Conservation, 2011, 1-8.

6 ICOM-CC, "The Conservator-Restorer: A Definition of the Profession," accessed 23.6.2021, http://www. icom-cc.org/47/about-icom-cc/definition-of-profession/\#.YNN5zr4za00. 
famous text "The Lining Cycle" by Westby Percival-Prescott in 1974. ${ }^{7}$ Wax-lining is now considered an unethical procedure, since it drastically changes the structural integrity of the painting, is irreversible, and can have negative effects on pigments by darkening them. ${ }^{8}$ Conservation and restoration ethics are not immutable, but continuously evaluated as new technical and material advances are introduced and old restorations are re-evaluated.

Since the turn of the $20^{\text {th }}$ century and from a contemporary perspective, restoration painting and more broadly conservation has evolved from what seems like an uncontrolled craft activity to an academic field pursuing control via ethical guidelines, treatises, and conservation and heritage organisations such as the ICOM (International Council of Museums), ICOMOS (International Council on Monuments and Sites), the IIC (The International Institute for Conservation of Historic and Artistic Works), the ICON (The Institute of Conservation), and different regional groups. ${ }^{9}$ Dr. Salvador Muñoz Viñas explains how the contemporary theory of conservation has its roots in the writings of the $19^{\text {th }}$ century art and architecture critic John Ruskin, who thought that ruins should be left as they were and no to be rebuilt. In contrast are the writings of Eugène Viollet-le-Duc, an architect and restorer likewise active in the $19^{\text {th }}$ century, who in turn felt that the filling in of "blanks" in damaged buildings was justified. These two authors represent the polar

7 David Bomford, "The Conservator as Narrator: Changed Perspectives in the Conservation of Paintings," Personal Viewpoints. Thoughts about Paintings Conservation, edited by Mark Leonard (Los Angeles: Getty Conservation Institute, 2001), 1-14.

$8 \quad$ Ibid

9 Muñoz Viñas, Contemporary Theory of Conservation, 2.

A fairly comprehensive list of organisations dealing with conservation and cultural heritage around the world can be found on the CoOL (Conservation OnLine) website: https://cool.culturalheritage.org/byorg/ orgs.html. The CoOL website is managed by FAIC (The Foundation for Advancement in Conservation). opposites of restoration attitudes in conservation. A third architecture scholar of importance for conservation history is the Italian architect and art historian Camillo Boito, who established the principle that the original and restored parts of an object should be clearly discernible "which allows for honest restoration of the object". ${ }^{10}$ Restoration painting has been discussed in conservation conferences throughout the years and the number of publications on suitable methods and materials has been increasing. ${ }^{11}$ It may be noted, though, that one of the earliest remarks on altering or retouching paintings can be found in the writings of Giorgio Vasari. ${ }^{12}$

There is a pronounced tendency in art conservation to break free from the amateurish background of modifying and altering paintings. Not only has conservation developed into an academic discipline that applies the research methods of natural sciences, but restoration painting has also been approached as a scientific method for filling in areas of loss. One of the most cited theorists in the conservation field is Cesare Brandi, who developed a specific method of restoration painting,

10 Muñoz Viñas, Contemporary Theory of Conservation, 2.

11 Contemporary publications: Knut Nicolaus, The Restoration of Paintings (Cologne: Könemann, 1999); Joyce Hill Stoner \& Rebecca Anne (eds.), The Conservation of Easel Paintings (Abingdon, Oxon [England]; New York: Routledge, 2012); Johannes Karl Fink, Chemicals and Methods for Conservation and Restoration: Paintings, Textiles, Fossils, Wood, Stones, Metals, and Glass, (Hoboken, New Jersey: Wiley, 2017). Several older texts are still available, but these do not comply with modern conservation ethics. There are also some do-it-yourself books targeted for non-conservators on the market that will not be listed here for obvious reasons.

12 Sheldon Keck, "Some Picture Cleaning Controversies: Past and Present," Journal of the American Institute for Conservation 23, no. 2 (1984): 73-87, https://doi. org/10.2307/3179471. According to Keck, Vasari claimed Leonardo's Last Supper as being "ruined" after restoration work done by Lomazzo in 1584. The Last Supper was painted in an experimental way, which caused the paint to start crumbling shortly after its completion in 1479 , and it was subjected to several interventions by different artist-restorers. 
the tratteggio, which strives to minimise those aspects that are considered unethical in restoration as part of conservation ${ }^{13}$ : unfounded invention, and modification of the original. ${ }^{14}$ Tratteggio is a restoration method that on closer inspection is clearly discernible from the original painting and has for this reason been considered an ethical method of restoration painting. Conservator and researcher in Museum Studies, Miriam Clavir writes about the professional values in conservation and draws attention to the ideal of science in conservation. Methods adopted from the natural sciences in material investigation have been seen as the best way to preserve the integrity of an object. ${ }^{15}$ I see the overpowering scientificism in conservation as having resulted in a quest for an objective, scientifically sound and justifiable method of restoration painting. However, I find that the discourse surrounding conservation and science often fails to consider areas that are beyond scientific examination and methods, such as personal taste, tactile knowledge, and artisanship, all of which are, in my view, essential for a good restoration. Contemporary conservation relies on methods and attitudes it has adopted from the natural sciences, one of these attitudes or aspirations being that of objectivity in research results and practical methods of conservation and restoration. ${ }^{16}$

The practices of restoration painting cover several different techniques, attitudes, and terminology towards handling a painting in a way that inflicts change on its surface. Restoration is considered

13 Restoration as part of conservation follows the ethical guidelines of conservation. Restoration as an independent activity done by someone other than a trained conservator does not necessarily follow these guidelines.

14 Muñoz Viñas, Contemporary Theory of Conservation, 3-4.

15 Miriam Clavir, "The Social and Historic Construction of Professional Values in Conservation," Studies in Conservation 43, no. 1 (January 1998): 1-8, https:// doi.org/10.1080/00393630.1998.12068815.

16 Muñoz Viñas, Contemporary Theory of Conservation, $67,69$. to be something that differs from solely stabilising, conserving, the already existing materials of the artefact. Restoration painting is considered here as adding something unoriginal, such as additions made on the painting's surface in most cases by someone else than the artists themselves. These additions are made with the intention of modifying the painting, most frequently to fill an area of loss in order to establish visual cohesion after damage on the surface of a painting.

Restoration painting as discussed here is a part of art conservation and follows the ethics of conservation. However, the act of restoration painting is an act of creativity and skill, that in my view cannot be fully controlled scientifically. To achieve a restoration that is aesthetically pleasing and at the same time follows the ethics of conservation, conservators use their knowledge of materials they have acquired through a scientific investigation of the object. They also rely on tactile knowledge, a sense of materiality and aesthetics, that is accumulated through their work and is difficult to convert into writing. This skill is not so dissimilar to the work of an artist, but the aim is very different. An artist usually aims for impact, where the (contemporary) conservator aims to fade into the background. Through the centuries, art has been handled and modified with much more freedom than the contemporary ethics of art conservation would allow. ${ }^{17}$ Alessandra Melucco Vaccaro discusses the way art and cultural heritage at large were restored "in the style of the original" and how statues have been moved and modified to serve new purposes. ${ }^{18}$ Melucco

17 Noémie Étienne, The Restoration of Paintings in Paris, 1750-1815. Practice, Discourse, Materiality (Los Angeles: Getty Conservation Institute, 2017), 10.

Maximiliaan P. J. Martens, "« Leave it or take it away »: ethical considerations on the removal of overpaintings", CeROArt. Conservation, exposition, Restauration d'Objets d'Art (Juin 2015), paragraph 28.

18 Alessandra Melucco Vaccaro, "Historical Perspectives," Historical and Philosophical Issues in the Conservation of Cultural Heritage (Los Angeles: Getty Conservation Institute, 1996), 262-267. 
Vaccaro states, that since the second half of the $19^{\text {th }}$ century, with the advent of a new scientific thinking in the humanities, the transforming and reuse of objects has been unacceptable. ${ }^{19}$ Examining these early acts of conservation, restoration and modification offers new insight into the history of conservation and the handling of art.

\section{Restoration painting historically}

Recently some accounts of poorly conducted restorations done by amateurs have received wide media coverage, such as Ecce Homo (ca. 1930) in the Spanish town of Borja by Elias Garcia Martinez, a fresco now also known as the "Monkey Christ", and a copy of Bartolomé Esteban Murillo's Immaculate Conception in a private collection in Valencia. ${ }^{20}$ In this chapter these poor amateur restorations function as a starting point, as they bear witness to a contemporary continuum of the long tradition of conservation and restoration of art done by amateurs and artists not trained to be conservators. These badly executed restoration jobs have understandably stirred irritation among professional conservators, not only because they have caused irreversible damage to an item of cultural heritage, but because they seem to demonstrate a lack of appreciation towards the profession of conservation; a specialised profession that has quite recently been developed to answer the need to control what happens to our cultural heritage and artefacts. The spoiled 'restorations' also demonstrate the fact that, when done professionally, restoration usually goes unnoticed by the public, but when it goes wrong, it is often painfully obvious even to the untrained eye and is often irreversible.

19

20 Sam Jones, "Experts call for regulation after latest botched art restoration in Spain," The Guardian International Edition, June 22, 2020, accessed 10.12.2020, https://www.theguardian.com/artanddesign/2020/ jun/22/experts-call-for-regulation-after-latest-botched-art-restoration-in-spain.
Prior to the establishment of conservation as a modern profession with its own education programme, museums and galleries commissioned artists to take on the restoration of artworks that needed care, such as the removal of a darkened layer of varnish, tears in the canvas, flaking paint, or other damages. ${ }^{21}$ In an article, which has become classic reading for art conservators, Sheldon Keck shares some of the most famous controversies surrounding the cleaning of paintings. The first one is from 1792, when the Louvre was preparing to open for the public and a commission was assigned for the cleaning and restoration of some two hundred old paintings from its collection. The work was done by artists not trained in conservation, which was criticised by their contemporaries. Critics claimed that the cleaning had been too harsh and had damaged the paintings. ${ }^{22}$ According to Keck, a second notable discussion about cleaning paintings surfaced in the $19^{\text {th }}$ century in which the effects of time on paintings was the focal point. ${ }^{23}$

Natural resin varnish darkens over time, which is well known a feature for artists and conservators, but there are differences between varnishes as regards how dark they become, however, as time passes, all natural resin varnishes darken to the point where the darkened layer to some extent obscures the colours under it. This darkening and obscuring of colours results in a desire to clean, replenish and replace the varnish layer at various intervals. In the so called cleaning controversies this passing of time manifesting as a darkened varnish layer was seen as something essential to old art and the removal of this layer was sometimes described as flaying the paintings. ${ }^{24}$ Another feature of natural resin varnish is its tendency to form small microcracks criss-crossing the surface. These cracks cause the varnish layer

\footnotetext{
21 Keck, "Some Picture Cleaning Controversies", 73.

22 Ibid., 74.

23 Ibid., 75.

24 Ibid., 76-77.
}

\section{TaHiTi 2/2021 $\mathbf{y}$}


to appear dull and opaque, again obscuring the colours and details of a painting and again calling for the removal of the old varnish layer. In 1863 Dr. Max von Pettenkofer patented a method (the Pettenkofer method), in which the surface of the painting was exposed to ethyl alcohol vapours. The vapours cause the varnish layer to soften, so that the microcracks are diminished for a period of time and the varnish layer seems bright again. With the Petterkofer method discovered, no large-scale cleanings were undertaken for several years. ${ }^{25}$

Cleaning was one of the reasons why earlier restoration painting took place as part of the conservation of paintings. The methods and solvents used were harsh and caused damage to the paint layer that then had to be covered with retouching and often exaggerated overpainting. Methods of and attitudes towards cleaning and restoring paintings have developed in the aftermath of the earlier cleaning controversies and the work of the amateur artist-restorers. ${ }^{26}$ Other reasons for restoring paintings are flaking paint due to deterioration of the paint film caused by either environmental stress or poor choice or handling of painting materials. Research conservator and art historian Kim Muir mentions three international conferences which have formed the discourse of modern restoration. The first of these was The International Conference for the Study of Scientific Methods for the Examination and Preservation of Works of Art held in Rome in $1930 .{ }^{27}$ Miriam Clavir considers this conference as a starting point for conservation as a modern discipline. ${ }^{28}$ What seems noteworthy is the emphasis on science already expressed in the name of the conference,

25 Ibid., 79.

26 Clavir, "The Social and Historic Construction of Professional Values in Conservation", 2.

27 Kim Muir, "Approaches to the reintegration of paint loss: theory and practice in the conservation of easel paintings," Studies in Conservation 54: sup1, DOI:10.1179/sic.2009.54.Supplement-1.19.

28 Clavir, "The Social and Historic Construction of Professional Values in Conservation", 3. and Clavir further confirms that this was the conference that acknowledged science "as a preferred methodology for solving problems in the preservation of historic cultural materials". ${ }^{29}$ The second conference Muir mentions is the Twentieth International Congress of the History of Art held in 1961 in New York. In this conference a session was dedicated to loss compensation. The third important conference, according to Muir, was the one held in 2002 at Yale, Early Italian Paintings: Approaches to Conservation. As Muir notes, there are several publications concerning retouching approaches, methods, and materials, but they are not literature reviews. ${ }^{30}$

Muir distinguishes three main lines of restoration painting: complete reintegration, visible retouching, and no reintegration. ${ }^{31}$ Complete reintegration means that the viewer will not be able to distinguish the restoration from the original. Early restoration painting was executed with no concept of conservation ethics or consideration for the integrity of original works. Following the contemporary ethics of conservation and restoration painting, the restoration should never exceed the area of loss, otherwise it is considered as overpainting and altering the original work to a complete forgery. However, this was not a problem for early artist-restorers or today's amateur restorers. As a reaction to these undisciplined restorations, a more controlled method of restoration painting was called for, and the well-known restoration method of tratteggio was developed in Italy. ${ }^{32}$ Before discussing the tratteggio method further, I will present a case study of a painting which had, at some point, experienced a transformation in the hands of an unknown conservator-restorer.

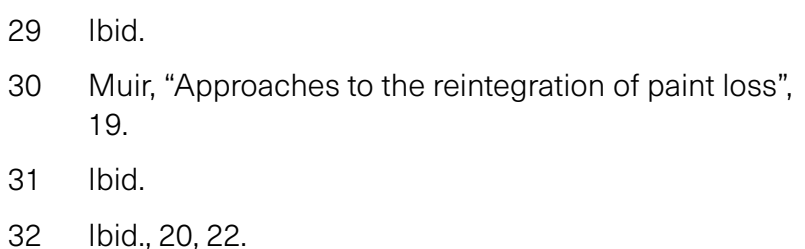

\section{TaHiTi 2/2021 $\mathbf{\Xi}$}



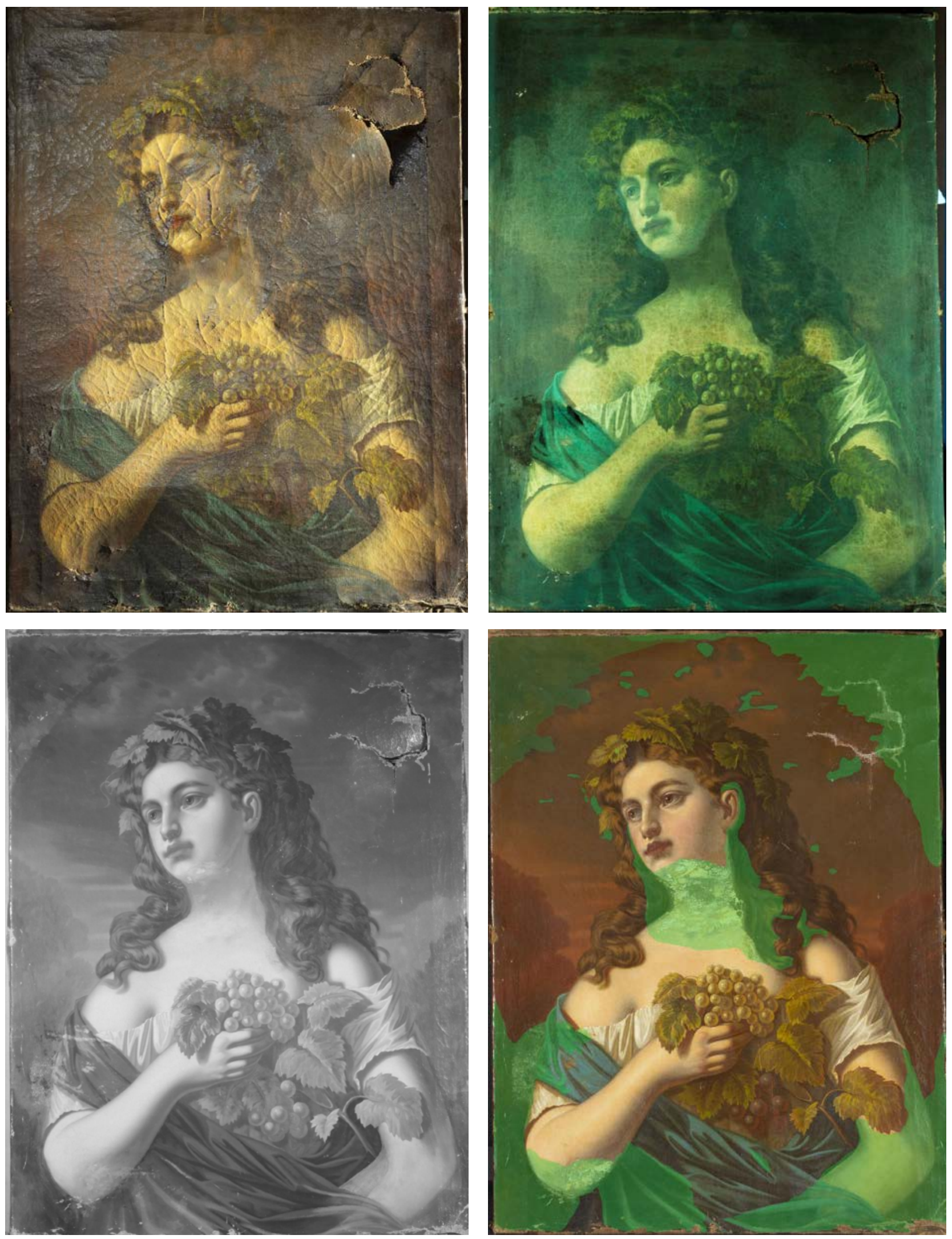

Figure 1. Marcel Johann von Zadorecki(?), untitled, undated. Oil on canvas, $78 \times 59 \mathrm{~cm}$. (1.1) Before conservation: sidelight or raking light, (1.2, top right) ultraviolet fluorescence. (1.3) During conservation: infrared reflectance and (1.4) areas of previous restorations and overpaintings marked with green. Photographs: Metropolia University of Applied Sciences, Emilia Laaksovirta and Annika Niemelä. 


\section{Revealing and concealing - a modified painting}

In this chapter, I will discuss the conservation and restoration of a painting on canvas that had large areas of previous overpainting. These earlier overpaintings were done in part as a conservation and restoration intervention of a tear in the canvas, but it became obvious that the overpaintings were also meant to significantly modify the depicted figure. The painting of a woman with a vine leaf garland on her head holding grapes, is by an unknown artist and has no background information or provenance; it was restored as an item of coursework on an art conservation course on paintings on canvas in the Conservation department of the Metropolia University of Applied Sciences in Helsinki, Finland in 2018-2019. The painting was in a poor state with severely damaged edges and a large triangular tear in the upper right corner (Fig. 1.1). A sidelight or a raking light was used to accentuate the topography of the surface of the painting and to better visualise the damages. Old and heavily yellowed varnish, with a strong greenish fluorescence typical of natural resin varnish in the ultraviolet fluorescence image (Fig. 1.2), was removed from the painting, and it became apparent that old restoration painting had been done in several large areas, especially near the neckline but also in all of the corners (Fig. 1.4). A UV-light shows restorations as darker areas since they are often painted on top of the varnish layer. ${ }^{33}$ The more recent restorations also appear darker than the older ones. $^{34}$

When the infrared reflectance image (Fig. 1.3) was studied, it seemed that the painting had been

33 René de la Rie, "Ultraviolet radiation fluorescence of paint and varnish layers," Journal of the European Study Group on Physical, Chemical, Biological and Mathematical Techniques Applied to Archaeology (PACT) 13: Scientific Examination of Easel Paintings, (Council of Europe, Parliamentary Assembly, Strasbourg, 1986), 91-108.

34 Ibid. altered in several ways: there were curving lines visible in the upper corners, which were not obvious in daylight, and the corners were heavily overpainted. There seemed to be an oval shape surrounding the central figure which suggested that the painting was intended to sit in an oval stretcher and frame. Later my student colleague Annika Niemelä decided to add a gilded oval passepartout to the frame (Fig. 5.3). The passepartout allowed for the old restorations in the corner areas to be left mostly intact and saved a significant amount of time in the restoration painting.

Because the painting was intended for coursework, the decision was made, after consulting the owner, to remove some of the overpainting to see what could be discovered under the restored sections. This is a laborious and time-consuming procedure. In this case there was time and willingness, within reason, to experiment and take some calculated risks. When removing large areas of overpaint, there is always a risk of encountering nothing underneath. This is why large scale overpaintings are often left intact, since the void discovered would need to be refilled and reinterpreted. The removal could then result in uncovering a complete ruin with no clues to help in the reconstruction. Removing and then restoring this kind of loss would just be replacing one interpretation with another. ${ }^{35}$ Reinterpreting a large area of loss requires reliable proof of what has previously been there, otherwise there can be the risk of the restoration of the painting being seen as a forgery.

The owner of the painting gave permission for removing some of the old restorations, with the knowledge of the risk that there might be no original paint layers under the overpainted areas. When working on removing old restorations, conservators today proceed with caution and

Martens, " Leave it or take it away »: ethical considerations on the removal of overpaintings," paragraph 20.

\section{TaHiTi 2/2021 $\mathbf{\Xi}$}


care using microscopes and different imaging techniques to control the progress. Controlling the progress is important to prevent the aforementioned risk of discovering a ruin. If it seems that removing the overpainted area is not going to produce a desirable result, it might be a better choice to leave the old restoration as it is, if it does not significantly disrupt the cohesion of the painting.

The varnish removal was controlled with ultraviolet light, to see if there were still thick areas of varnish intact, and to make sure it would not cause damage to the original paint layer. Surprisingly under the ultraviolet light inspection, the facial features of the central figure began to look somewhat different from those prior to conservation (Fig. 2.1). This observation increased our confidence that the decision to remove the overpainting and the heavy filling was justified and became even more apparent in a photograph taken after the filling in of the neck area had been removed (Fig. 2.2).

When the neck area of the figure was cleaned of varnish, it revealed a thick layer of filling and a damaged area (Fig. 3.1). The filling had been applied heavily over and beyond the damage (Fig. 3.2). Clearly in this restoration there had been no notion of minimal intervention.

A mass of brown hair had been added on both sides of the neck area. When the added hair was removed, and the neckline cleaned, the figure seemed to take on a more ambiguous or even a male appearance. Could the subject be identified as Dionysus or Bacchus, the male god of wine? Depictions of Bacchus or Dionysus often include more attributes than just vine leaves and grapes, such as wine in a bottle or a glass and large felines or their furs. ${ }^{36}$ An unfamiliar signature next to the figure's left arm was noted ending with the word 'Wien'. A bronze bust depicting Bacchus by

36 Cornelia Isler-Kerényi, Dionysos in Archaic Greece: An Understanding through Images (Leiden; Boston: Brill, 2007).
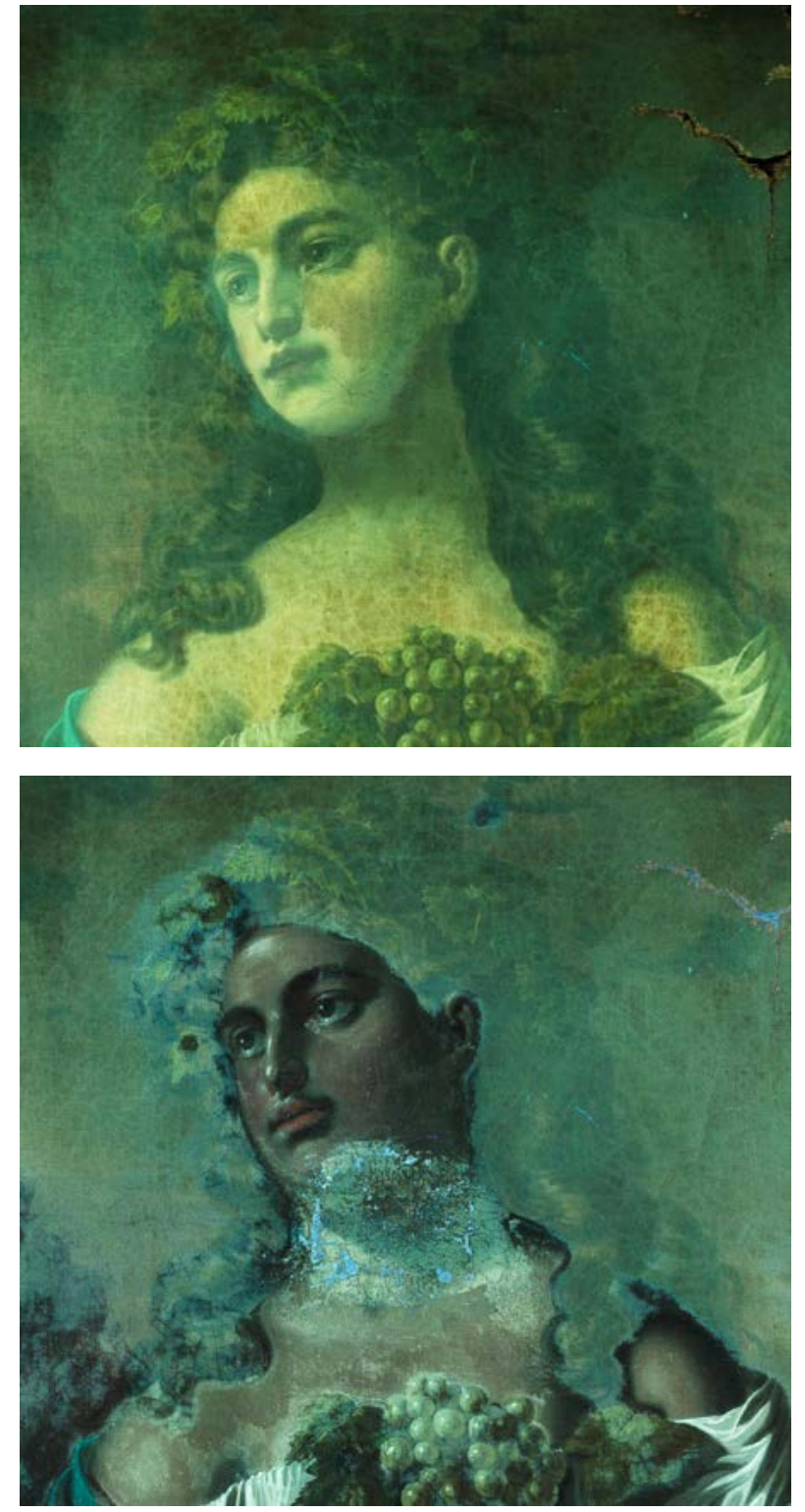

Figure 2. (2.1) Before conservation: detail image, ultraviolet fluorescence. (2.2) During conservation: detail image, ultraviolet fluorescence. Photographs: Metropolia University of Applied Sciences, Annika Niemelä.

Pier Jacopo Alari de Bonacolsi in the collection of The Kunsthistorisches Museum in Vienna (Fig. 4) has a very similar manner to the figure painting with a slightly tilted head, curly hair, vine leaves and grapes as well as soft and rounded features. This bust is also lacking all the other attributes associated with Bacchus. Another possible interpretation of the motif is a bacchante, or a maenad, a female follower of Bacchus. Bacchantes were a popular motif in European art 
Figure 3. (3.1) Detail image after varnish removal. (3.2) Detail image after the overpainting and filling have been removed. Photograph: Annika Niemelä.

from the sixteenth to the nineteenth century. ${ }^{37}$ Literary sources describe the bacchantes roaming the wilderness and engaging in violent rituals where they would make sacrifices to Bacchus or Dionysus by dismembering animals with their bare hands in a drunken frenzy. ${ }^{38}$

Professor of Drama J. Michael Walton notes that Greek tragedies were popular in Victorian theatre in England during the nineteenth century, including the Bacchae by Euripides. According to Walton, the Euripidian Dionysus seems to have been too extreme for the Victorians sensitivities, and was therefore demoted to the god of wine, instead of the ambiguous troublemaker and god of irrationality he is portrayed as in the Bacchae: "Dionysus could not possibly fit as god of that theatre, or god of anything else other than wine, which is where he was left, under the name of Bacchus, nothing more sinister than an underage drinker, his 'plump white arms imbrued with crimson' (Endymion IV 2-123)." ${ }^{39}$

The old restorations and massive overpainting obscured the possibilities of recognising the original subject of the painting. With its thinned neckline the figure had been modified to resemble a female rather than a male. The figure has a hazy woodland scenery painted in the background (Fig. 5.2), which would further hint to a bacchanalian reading of the motif. As noted earlier, the bacchantes depicted in literature were

37 Thayer Tolles, Bacchante and Infant Faun: Tradition, Controversy, and Legacy (New York: The Metropolitan Museum of Art, 2019), 13-15.

38 Ibid., 15; "Bacchants," The Oxford Companion to Classical Literature, edited by M.C. Howatson, Oxford University Press, 2011, https://www.oxfordreference.com/ view/10.1093/acref/9780199548545.001.0001/acref-9780199548545-e-0457?rskey=qbCEoR\&result=1.

39 J. Michael Walton, "Dionysus: The Victorian Outcast," Victorian Review 34, no. 2 (2008): 185-99.
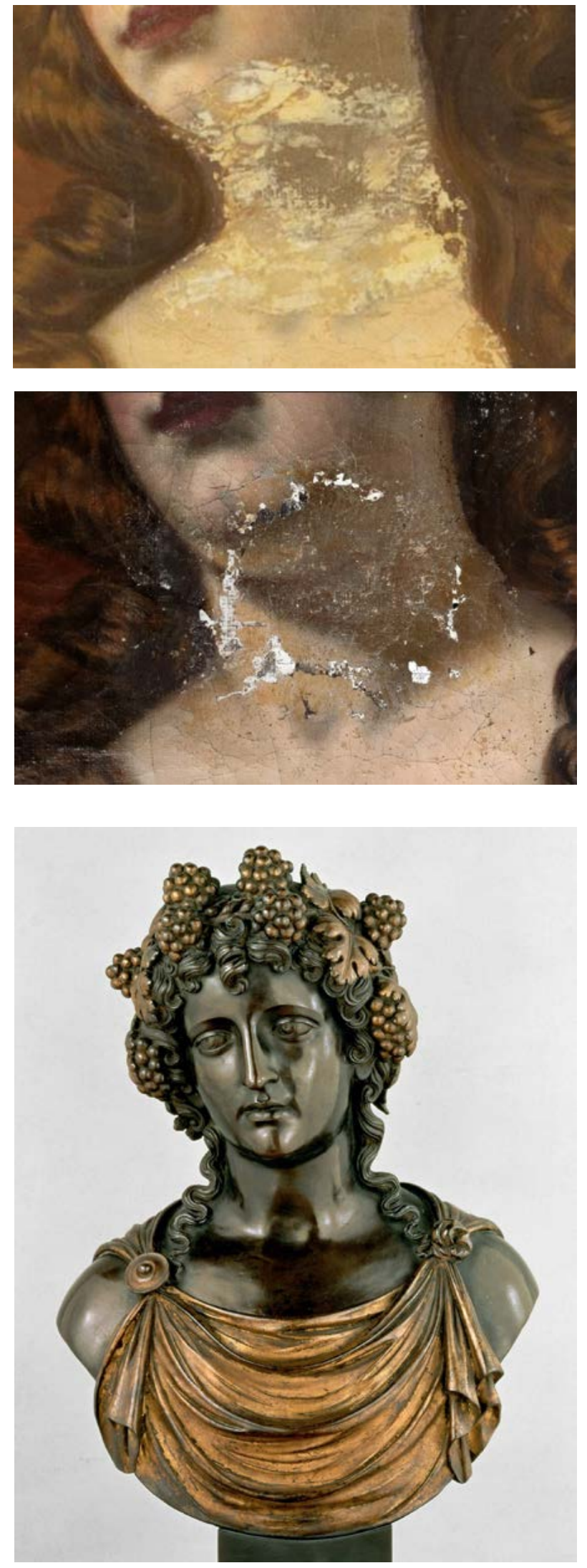

Figure 4. Pier Jacopo Alari de Bonacolsi, Bacchus (1520/22). Partially gilded bronze, $59 \times 43 \times 27 \mathrm{~cm}$. Photograph: Kunsthistorisches Museum Wien, Kunstkammer, CKHM-Museumsverband (CC BY-NC-SA 4.0). https://www.khm.at/de/object/360ec4ad34/

\section{TaHiTi 2/2021 $\mid \mathbf{V}$}




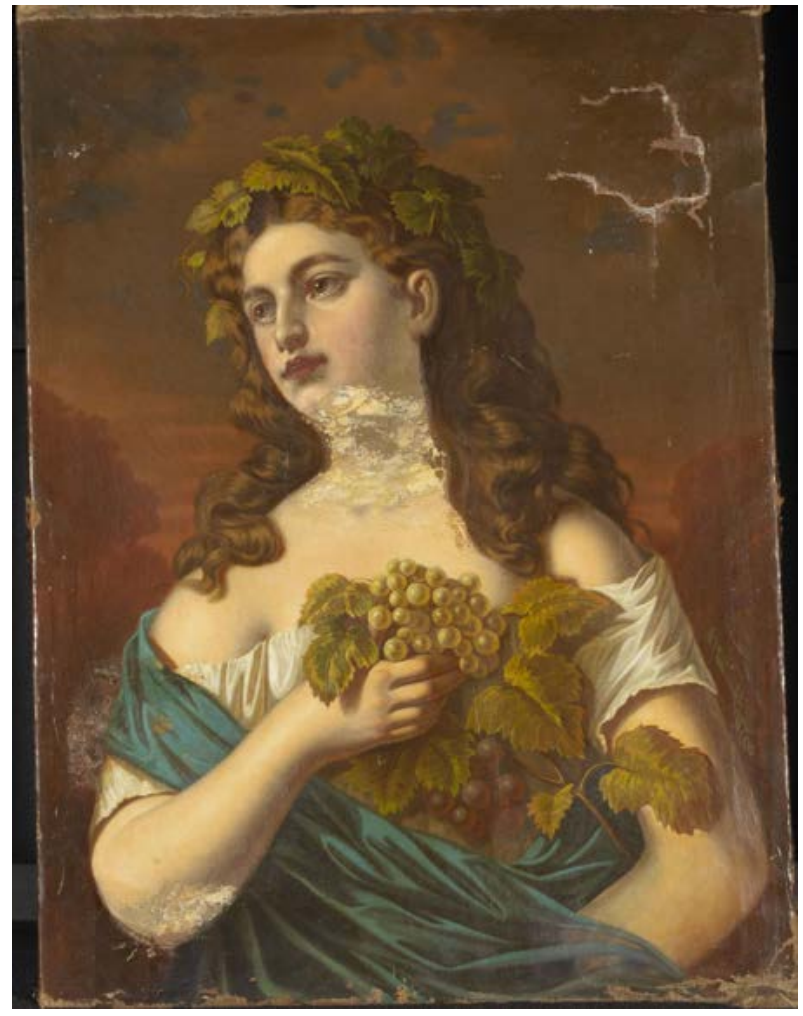

the violent, drunken, and frenzied followers of Bacchus. The figure in the painting seems rather sedate in contrast to this description. The figure seems unapproachable, lost in its thoughts gazing into the remoteness - rather god-like. This sedateness, in my view, would point more towards interpreting the figure as Bacchus. In the absence of any clear attributes of Bacchus, such as wine and feline fur, it could just as well be viewed as a female bacchante. With the removal of the restorations the motif was revealed as having an interesting interpretation as a possible male figure, as construing the figure to be physiologically female was now perhaps less apparent. The figure remains androgynous and possibly this slight ambivalence of gender was the reason for the modification by excessive overpainting. Unfortunately, there is no record of the painting prior to its purchase by the current owner but based on material evidence, such as the use of a thin layer of light grey priming or ground, it
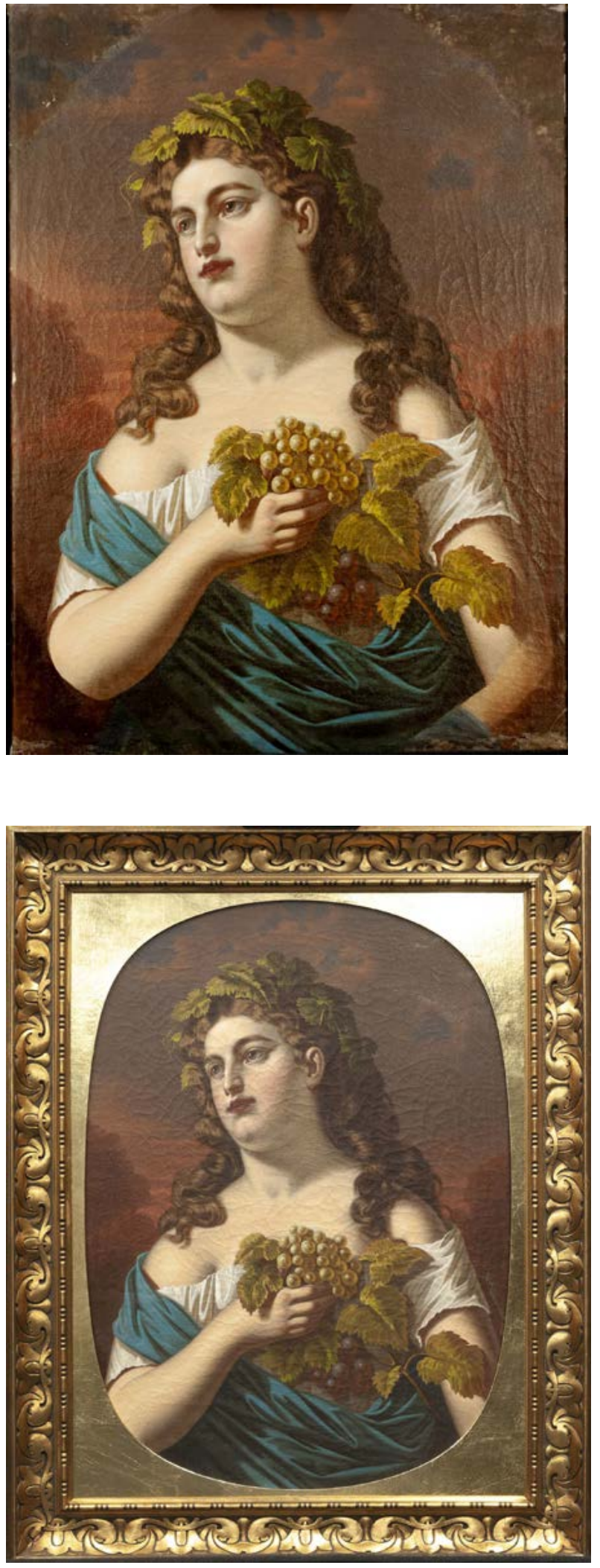

Figure 5. (5.1) Before and (5.2) after conservation. (5.3) With frame. Photographs: Emilia Laaksovirta and Annika Niemelä. 
was estimated to have been painted in the $19^{\text {th }}$ or early $20^{\text {th }}$ century in Vienna. ${ }^{40}$

The Kunsthistorisches Museum in Vienna was able to identify the painter as Marcel Johann von Zadorecki, who worked in Austria and Poland. ${ }^{41}$ There is little reliable information available about the artist. It seems the painter had a fascination for female masculinity, or exotic androgyneity, when considering the paintings attributed to von Zadorecki in the artnet auction website. ${ }^{42}$ The Thieme-Becker biographical dictionary of artists mentions an altarpiece painted by von Zadorecki in 1780 , but this seems unlikely, given that auction houses list paintings by von Zadorecki painted as late as the 1870 's or even early 1900 's. ${ }^{43}$ It is possible that auction houses are confusing two painters, both named Zadorecki, which would explain some of the confusion concerning the active years of the painter. There could also be a typo in the Thieme-Becker which would need further investigation. The possible identification of the painter together with the material evidence of the grey ground layer typical to the period, suggest that the painting was painted probably in the late 19 th or early 20 th century. ${ }^{44}$ The modification of the neck and chin area was almost

40 Maartje Stols-Witlox, "Grounds, 1400-1900," Conservation of Easel Paintings (London: Routledge, 2012), 161-185.

41 Email correspondence, 8.6.2021.

42 "Marcel Johann von Zadorecki (Austrian/Hungarian, 1878-1939)," accessed 10.9.2021, http://www.artnet. com/artists/marcel-johann-von-zadorecki/.

43 Ulrich Thieme \& Felix Becker, Allgemeines Lexikon Der Bildenden Künstler Von Der Antike Bis Zur Gegenwart (Leipzig, 1907), 379.

Agra Art auction house website claims that paintings by von Zadorecki have dates as late as 1936. Agra Art, "Marcel Johann von Zadorecki," accessed 19.6.2021, https://sztuka.agraart.pl/autor/licytacje/3209/marcel-johann-von-zadorecki.

44 Metropolia University of Applied Sciences, Conservation department, Conservation report T-070917-1; Maartje Stols-Witlox, “Grounds, 1400-1900," 176-177. certainly done in response to the tear damage in the canvas, but the added hair had no other function than to further slim down and thus feminise the figure. Without any further background information, it is difficult to pinpoint when exactly these modifications were made but judging by the choice of an already hardened film of oil paint in the overpainting, rather than modern conservation paint mediums that would comply with the ideal of removability, the restoration might have been done sometime between the early and late 20 th century.

The case of the modified Bacchic painting illustrates how, through a scientific study of the painting, it became obvious that the alterations which could safely be removed had been done on top of the original paint layer. In this case the modifications and overpainting were extensive, as is common in earlier restorations. In the Bacchus/bacchante case, it seems that the damage to the neck area was treated as a conservation procedure, and then either by intention or by getting carried away, the overpainting modifying the figure was conducted. Overpainting and modification of a paintings motifs are not in line with contemporary conservation and restoration ethics and practices, but these phenomena are something conservator-restorers restorers need to tackle regularly when dealing with old art. Lavish overpainting is one of the main motivations for the development of a more scientific and objective method for restoration painting, to minimise interpretation and invention. I will now discuss the tratteggio method of restoration painting as a scientific solution for uncontrolled and unethical restorations.

\section{Tratteggio, a scientific method for restoration painting}

Tratteggio was developed in Italy in the 1940s by Cesare Brandi as a near-scientific method of 
restoration painting. ${ }^{45}$ Similar practices of minimal intervention by hatching or dotting had been done earlier, but not methodically. ${ }^{46}$ Trattegio aimed at a restoration which was true to the object and obvious to the viewer, so that there would be no possibility of interpreting the restoration as a forgery or a manipulation. ${ }^{47}$ Following Kim Muir's classification, tratteggio refers to visible, or differentiated retouchings which: "aim to reintegrate the image by reducing the visual impact of the loss while ensuring that the restoration is clearly recognizable as such" ${ }^{48}$

Tratteggio has its roots in the ideas of Gestalt psychology and phenomenology. The idea is that an area of damage, loss, or lacuna becomes a form in itself which disrupts and begins to dominate the viewing of the image. To re-establish the pictorial cohesion of the image, the disruptive lacuna must be treated so that it fades into the background and allows the image to be viewed as a harmonious whole. ${ }^{49}$ Tratteggio (rigatino) is realised with vertical lines using a restricted palette of colours, with each one-coloured stroke blending in with the other strokes next to each other creating an illusion of an evenly coloured area (Fig. 6). Tratteggio has two other variants, selezione chromatica, where the lines do not have to be vertical but can be curvy to adapt to the composition, and astrazione chromatica, where large areas of losses can be filled with a "gener-

45 Lucija Močnik Ramovš \& Hirci Barbka Gosar, "Retouching: How and with What? International Workshop on Retouching Oil Paintings and Wooden Polychrome Sculpture," Varstvo Spomenikov, no. 44 (2008), 222227.

46 Muir, "Approaches to the reintegration of paint loss," 23.

47 Muñoz Viñas, Contemporary Theory of Conservation, 67-69.

48 Muir, "Approaches to the reintegration of paint loss," 22.

49 Lucija Močnik Ramovš \& Hirci Barbka Gosar, "Retouching," 223; Maisey, Smithen, Soler \& Smith, "Recovering from destruction," 4. al neutral colour" to reintegrate the loss. ${ }^{50}$ This method is often used, when a painting has large areas of loss that cannot be refilled with the help of archival sources. Large restorations call not only for a justified plan for the filling but also artistic capability from the conservator, since all restorations are still done by hand.

One of the problems with tratteggio and its derivatives is their apparent inability to take into consideration the amount of interpretation needed in the process of restoration. Firstly, one needs to identify the loss as a loss, secondly, one needs to decide whether this loss is disruptive in such a way that it prevents the identification and understanding of the nature of the object. If the loss is so significant, how can the restorer fill it objectively without interpreting too much?

Conservation and restoration rely on science as an objective method for material investigation as well as restoration. Muñoz Viñas criticises this pursuit of a scientific truth in conservation and claims that even the perceiving of damage on an object "is a result of taste and prejudices that can vary among persons, cultures, and with time". ${ }^{51}$ Muñoz Viñas also claims that a painting with restorations has, in fact, two painters and that the only authentic state an object can have is the current one: "Any attempt to take the object back to another presumed and favoured state is first and foremost a matter of choice". ${ }^{52}$ Muñoz Viñas also views scientific restoration as an oxymoron, "because no scientific, objective reason to substitute a presumed, preferred past state of an

50 Grenda, "Tratteggio retouch and its derivatives," paragraph 14.

51 Salvador Muñoz Viñas, "Contemporary Theory of Conservation," Studies in Conservation 47 (January 2012), 25-34, DOI:10.4324/9780080476834.

52 Ibid., 26. 


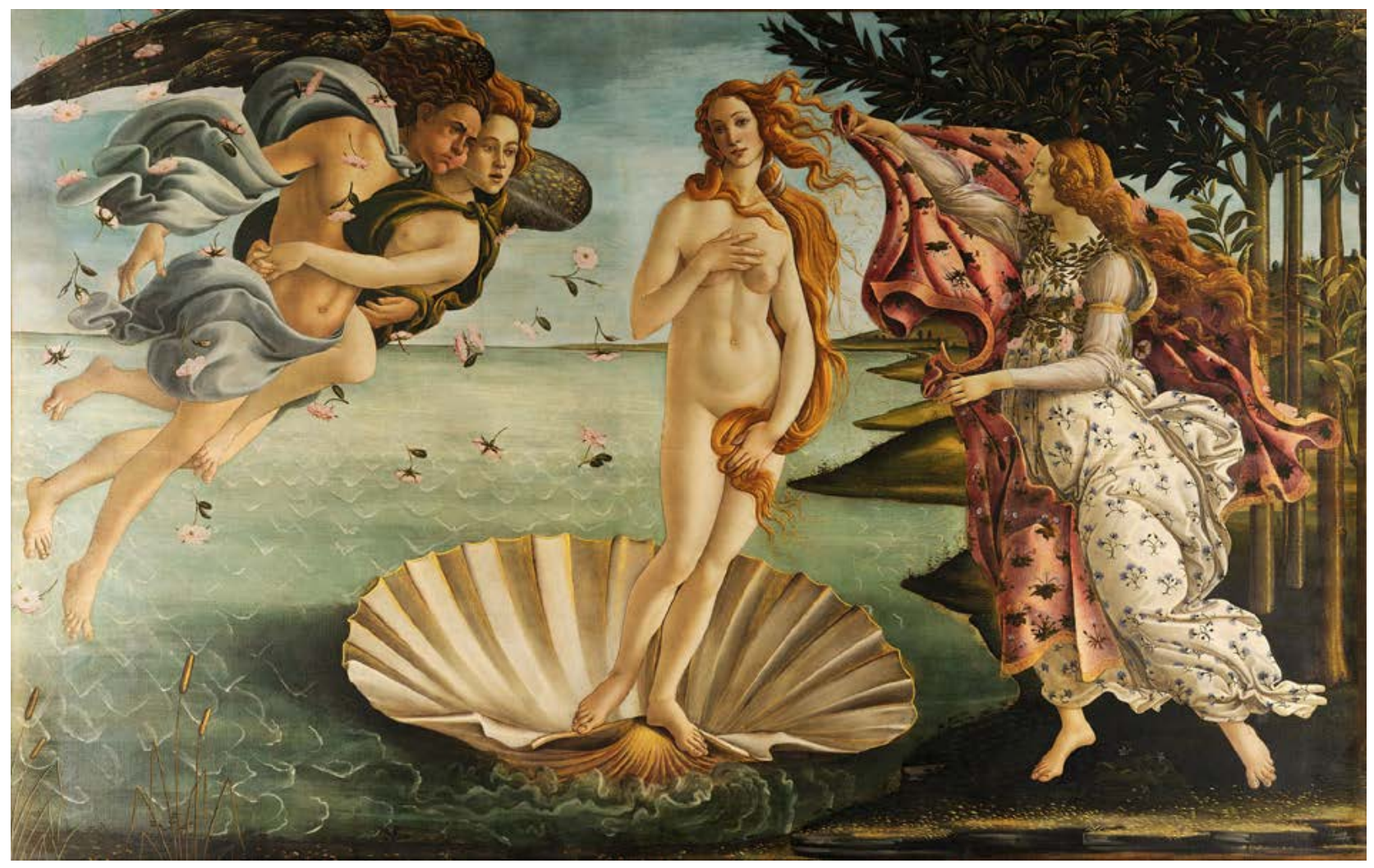

Figure 6. (6.1) Sandro Botticelli, The Birth of Venus, c. $1484-1486$. Tempera on canvas. $172.5 \mathrm{~cm} \times 278.9$ $\mathrm{cm}$. (6.2) Tratteggio restoration visible in the upper left corner on The Birth of Venus. Photograph: Wikimedia Commons.

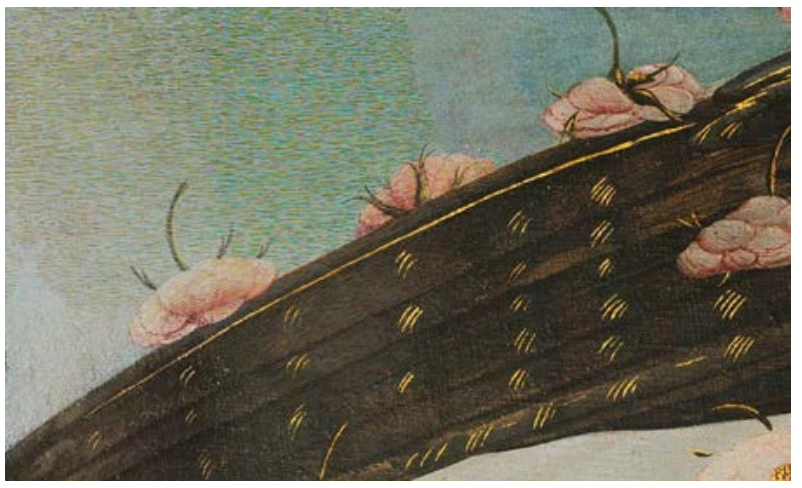

object for the present one (which is necessarily, undoubtedly authentic) exists". ${ }^{53}$

Following the thoughts of Muñoz Viñas, the earlier presented case of removing an extensive overpainting raises some fundamental questions about the ethics of the removal. This is by no means an insignificant question, but it is still one that is seldom addressed in conservation reports and case articles. In general, old restorations are not considered worthy of salvaging when they are not the work of the original artist. The removal

is often justified with science, as was the case in the Bacchus/bacchante painting: through scientific, meticulous investigation it became clear that the restoration had been performed on top of the original paint layer by someone other than the original artist. Even so, we cannot escape the fact that individuals made the choice to remove the majority of the overpainting, causing a significant and irreversible change in the potential iconographical interpretation of the painting. 


\section{Science and invention in contemporary restoration painting}

As stated earlier, conservation and restoration have been developed from craftmanship through the introduction of the so called hard natural sciences into an academic discipline. The pronounced role of natural sciences in decision making has been criticised. Even after this criticism, new scientific inventions to aid restoration have been introduced, as if there were a circular movement in the development of conservation and restoration. A quest for a scientific method of restoration painting has resurfaced through new technology involving the tracking of eye movement and the possibility to make digital sketches of the planned restoration. In my view, advances in science and technical methods offer interesting new tools, but the human factor can never be fully regulated or measured, nor should it be. Tate Britain's Destruction of Pompeii and Herculaneum (1821) by John Martin suffered severe flood damage in 1928 and was deemed "irretrievably lost" with a good portion of the original canvas missing and considerable damage to the remainder. The painting was stored away for almost a century before the decision to restore it in $2009 .{ }^{54}$

Paintings conservator Sarah Maisey, the conservator in charge of the conservation process of the painting, made digital models of the intended restoration. These models were shown to an audience of twenty naïve (non-conservator) viewers and their eye movements were tracked. The models were an illusionistic infill, a neutral infill with a single colour, a muted infill with toned down colours and an abstracted infill based on the illusionistic one. The viewers were also asked about their preference as regards the models in a separate questionnaire and the majority preferred the illusionistic model followed by the abstracted

54 Maisey, Smithen, Soler \& Smith," Recovering from destruction," 1.

version. ${ }^{55}$ The final restoration was planned and executed using three different source images of the intact composition. ${ }^{56}$ Maisey responded in an email to me, that a restoration of this proportion would not have been undertaken without any existing imagery to guide the work, since it would have called for a significant invention and would have been considered unethical. ${ }^{57}$

The use of digital restorations is becoming more common in conservation, but it is time consuming and requires technical skills and access to suitable software and hardware. ${ }^{58}$ Even with these advances in modelling the restoration before realising it, the actual restoration work is still executed manually. Conservator-restorers use their skills as a painter and judgement as a conservator when making decisions about the restoration, often as it progresses. This visual judgement is guided by the goals that are set for the restoration often in consultation with other museum professionals such as curators and art historians, or by the ethics of conservation and restoration, but also by personal taste and preferences to some degree.

Considering the case of the Bacchus/bacchante painting discussed above and similar paintings that have undergone such treatments resulting in drastic change, it might be interesting to consider these types of advancements in technology with digital modelling combined with augmented reality in exhibition spaces, both virtual and actual. As a part of ethical and professional conservation, all work is documented with photographs and a written report that explains the materials and methods used in the conservation. Even with the painting with its transformed iconography, there is a record of its earlier stage, showing the

56 Ibid

57 Sarah Maisey, email correspondence, 16.12.2020.

58 Another example of digital modelling as part of conservation and restoration: Grenda, "Tratteggio retouch and its derivatives," paragraph 17-18.

\section{TaHiTi 2/2021 $\mathbf{y}$}


damage and previous alterations. Augmented reality is more broadly used on archaeological sites, where digital modelling helps the audience to visualise what the site was once like. Perhaps something like this could be applied in art museum settings with paintings that have a history of modification, to visualise changes more concretely. One could argue here that the perception of a painting is very different to the perception of an archaeological site or object and that the painting should be received and respected as it appears at the moment of perception, without the burden of its material history. I would argue the opposite, and in my view the knowledge of the material, its ageing, and the treatment history of the painting, especially when that history is a long one, increases the understanding and appreciation of a piece of art, not only as a material object, but as a work of art that has been assessed as worthy of treatments which, for the most part, aim at prolonging its life span.

\section{Conclusion}

In this paper, I have discussed the history of restoration painting as part of conservation. The practice of restoration painting, and more broadly conservation of art, has a history as an amateur activity executed by artists or other craftsmen. Amateur restorers have caused, and sadly are still causing, irreversible damage and alterations to paintings and, as a reaction, a method of controlled and ethical restoration painting was developed after the second world war in Italy, the tratteggio. This article presented a case study of a painting possibly by Marcel Johann von Zadorecki, that had significant overpainting as a result of an earlier conservation and restoration that was done to repair a tear in the canvas; however, it also modified the iconography of the painting, as it reduced the gender ambiguity. This modification might have been intentional, but at least it was not considered problematic at the time of its creation. It exemplifies an unethical alteration that the scientific method of tratteggio aims to avoid. When examining and treating the painting, it became clear that it was possible to remove the later overpainted modifications without causing harm to the original paint layer. The removal of old overpainting is not an easy decision, as was discussed earlier. It risks discovering a ruin and always irretrievably changes the ways in which a painting can be seen.

The tratteggio method or restoration painting was thought to be a scientific and objective way of restoring since its hatched lines are clearly discernible from the original painting on closer inspection. The tratteggio and more broadly the theory of conservation has in my opinion struggled to find a balance between striving for objective scientificity and the need for the conservator to have high artisan skills when practicing their profession. The role of science in contemporary practices of conservation and restoration is significant, and new innovative ways to explore the possibilities in restoration painting have been tested and applied in practice. Science and academic professionalism seem to have become pronounced in the conservation field as a way of breaking free from the history of craftsmanship and amateur activity and in controlling the act of restoration. Restoration painting needs further studies to better understand the methods, attitudes, ethics and impacts it has had and continues to have on art and art history. Museum collections harbour paintings that have been restored and modified, and these modifications are not always obvious to the naked eye. Examining these restored paintings increases our knowledge about their individual histories and more broadly about the aesthetics and ethics of art restoration.

Art history MA, conservator BA, Emilia Laaksovirta is working on a doctoral thesis concerning restoration painting as an art historical phenomenon and as a conservation practice in the University of Turku. The thesis work has received funding from Koivisto foundation and Finnish Cultural Foundation. 


\section{References}

Agra Art. "Marcel Johann von Zadorecki." Accessed 19.6.2021. https://sztuka.agraart.pl/autor/licytacje/3209/marcel-johann-von-zadorecki.

Artnet. "Marcel Johann von Zadorecki (Austrian/Hungarian, 1878-1939)." Accessed 10.9.2021. http:// www.artnet.com/artists/marcel-johann-von-zadorecki/.

Australia ICOMOS. "Burra Charter \& Practice Notes." Accessed 17.12.2020. https://australia.icomos. org/publications/burra-charter-practice-notes/.

Bomford, David. "The Conservator as Narrator: Changed Perspectives in the Conservation of Paintings." Personal Viewpoints. Thoughts about Paintings Conservation, edited by Mark Leonard, 1-14. Los Angeles: Getty Conservation Institute, 2003.

Clavir, Miriam. "The Social and Historic Construction of Professional Values in Conservation." Studies in Conservation 43, no. 1 (January 1998): 1-8. https://doi.org/10.1080/00393630.1998.12068815.

De La Rie, E. Rene. "Ultraviolet radiation fluorescence of paint and varnish layers." Journal of the European Study Group on Physical, Chemical, Biological and Mathematical Techniques Applied to Archaeology (PACT) 13: Scientific Examination of Easel Paintings, edited by R. van Schoute and H. Verougstrate-Marcq, 91-108. Council of Europe, Parliamentarly Assembly, Strasbourg, 1986.

Étienne, Noémie. The Restoration of Paintings in Paris, 1750-1815. Practice, Discourse, Materiality. Los Angeles: Getty Conservation Institute, 2017.

Grenda, Magdalena. "Tratteggio retouch and its derivatives as an image reintegration solution in the process of restoration. Case study: restoration of a 20th century lithograph film poster by Stefan Norblin." CeROArt. Conservation, exposition, Restauration d'Objets d'Art, no. 1 (15 November 2010).

ICOM-CC. "The Conservator-Restorer: A Definition of the Profession." Accessed 23.6.2021. http:// www.icom-cc.org/47/about-icom-cc/definition-of-profession/\#.YNN5zr4za00.

Isler-Kerényi, Cornelia \& Wilfred G.E. Watson. Dionysos in Archaic Greece: An Understanding through Images. Leiden; Boston: Brill, 2007.

Jones, Sam. "Experts call for regulation after latest botched art restoration in Spain." The Guardian International Edition, June 22, 2020. https://www.theguardian.com/artanddesign/2020/jun/22/experts-call-for-regulation-after-latest-botched-art-restoration-in-spain.

Keck, Sheldon. "Some Picture Cleaning Controversies: Past and Present." Journal of the American Institute for Conservation 23, no. 2 (1984): 73-87. https://doi.org/10.2307/3179471.

Maisey, Sarah, Patricia Smithen, A. Soler \& Tim Smith, "Recovering from destruction: the conservation, reintegration and perceptual analysis of a flood-damaged painting by John Martin." ICOM-CC: 16th triennial conference, Lisbon, 19-23 September 2011, Paris: ICOM Committee for Conservation, 2011, 1-8.

Martens, Maximiliaan P. J. " "Leave it or take it away »: ethical considerations on the removal of overpaintings." CeROArt. Conservation, exposition, Restauration d'Objets d'Art, Juin 2015. https://doi. org/10.4000/ceroart.4765.

Melucco Vaccaro, Alessandra. "Historical Perspectives." Historical and Philosophical Issues in the Conservation of Cultural Heritage, edited by Nicholas Stanley Price, M. Kirby Talley Jr. and Alessandra Melucco Vaccaro, 262-267. Los Angeles: Getty Conservation Institute, 1996.

Metropolia University of Applied Sciences, Conservation department. Conservation report T-070917-1.

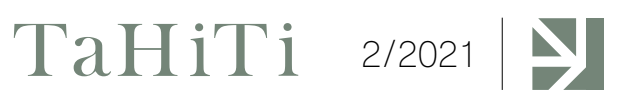


Muir, Kim. "Approaches to the reintegration of paint loss: theory and practice in the conservation of easel paintings." Studies in Conservation 54:sup1, 19-28. DOl:10.1179/sic.2009.54.Supplement-1.19.

Muñoz Viñas, Salvador. Contemporary Theory of Conservation. Oxford: Routledge, 2005.

Muñoz Viñas, Salvador. "Contemporary Theory of Conservation." Studies in Conservation 47 (January 2012): 25-34. DOI:10.4324/9780080476834.

"Bacchants." The Oxford Companion to Classical Literature, edited by M. C. Howatson. Oxford University Press, 2011. https://www.oxfordreference.com/view/10.1093/acref/9780199548545.001.0001/ acref-9780199548545-e-0457?rskey=qbCEoR\&result=1.

Ramovš, Lucija Močnik \& Hirci Barbka Gosar. "Retouching: How and with What? International Workshop on Retouching Oil Paintings and Wooden Polychrome Sculpture." Varstvo Spomenikov, no. 44 (2008): 222-227.

Rijks Museum. "Operation Night Watch". Accessed17.12.2020. https://www.rijksmuseum.nl/en/ nightwatch.

Stols-Witlox, Maartje. "Grounds, 1400-1900." Conservation of Easel Paintings, edited by Joyce Hill Stoner and Rebecca Rushfield, 161-185. London: Routledge, 2012.

Thieme, Ulrich \& Felix Becker. Allgemeines Lexikon der bildenden Künstler. Von der Antike bis zur Gegenwart. Leipzig: Verlag von Wilhelm Engelmann, 1907, 379.

Tolles, Thayer. Bacchante and Infant Faun: Tradition, Controversy, and Legacy. New York: The Metropolitan Museum of Art, 2019.

Walton, J. Michael. "Dionysus: The Victorian Outcast." Victorian Review 34, no. 2 (2008): 185-199. 